\title{
HIGH AMOUNT OF DINOPHYSISTOXIN-3 IN Mytilus chilensis COLLECTED IN SENO DE RELONCAVÍ, CHILE, DURING MASSIVE HUMAN INTOXICATION ASSOCIATED WITH OUTBREAK OF Vibrio parahaemolyticus
}

\author{
Carlos GARCÍA, Valeria SCHONSTEDT, Juan Palbo SANTELICES and Néstor LAGOS \\ Laboratorio Bioquímica de Membrana, Departamento de Fisiología y Biofísica, \\ Facultad de Medicina, Universidad de Chile, \\ Casilla 70005, Correo 7 Santiago, Chile
}

(Received June 9, 2006; Accepted June 15, 2006)

\begin{abstract}
This study describes the detection of high amount of 7- $O$-acyl-derivative dinophysistoxin-1 (Dinophysistoxin-3) in filter bivalves collected on February 2005 in the Seno de Reloncaví, Puerto Montt City, Southern Chile, in the same period of time where an intoxication episode was associated with the presence of Vibrio parahaemolyticus in shellfish.

The Diarrhetic Shellfish Poisoning (DSP) mouse bioassay of mussel extract samples, performed as described for regulatory testing, were negative to DSP toxins. Therefore, the same mussel samples collected from 8 places of Seno de Reloncaví were then analyzed by the HPLC-FLD method with pre-column derivatization procedure for DSP toxins.

The samples showed mainly 7-O-acyl-derivative dinophysistoxin-1 (Dinophysistoxin-3) in concentrations ranging from $190.3 \pm 6.8$ to $311.1 \pm 4.8 \mathrm{ng}$ of DSP toxin/g hepatopancreas and less amounts of Dinophysistoxin-1 ranging from $1.9 \pm 1.5$ to $11.7 \pm 4.6 \mathrm{ng}$ of DSP toxin/g hepatopancreas. After alkaline hydrolysis of the mussel extracts, $279.4 \pm 7.2 \mathrm{ng}$ of Dinophysistoxin-1/g hepatopancreas (mean \pm SEM, $\mathrm{N}=6$ ) were found in mussel extracts (Zone 8). These data showed that these shellfish samples are contaminated with the ester form 7- $O$-acyl-derivatives of Dinophysisyoxin-1, far beyond the safe regulatory limit. This paper also shows a direct relation between lipid content in the mussel tissue extracts and the levels of Dinophysistoxin-3. The 7-O-acyl-derivative dinophysistoxin-1 ester was the only compound associated with DSP toxins detected in the shellfish samples, and in view of the fact that metabolic transformation of Dinophysistoxin-3 into Dinophysistoxin-1 in humans has recently been described in the literature, the consumption of shellfish contaminated with 7-O-acyl-derivatives dinophysistoxin-1 could be a major reason that explains the diarrhetic symptoms shown by the intoxicated patients.
\end{abstract}

KEY WORDS: Dinophysistoxin-3, Dinophysistoxin-1, DSP human intoxication, Vibrio parahaemolyticus, Filter bivalves

\section{INTRODUCTION}

Toxic harmful algal bloom (HAB) arises due to the exponential growth of toxins producing dinoflagellates or diatoms. Blooms are triggered by multiple environmental factors, such as a nutrient increase in the water column, increasing utilization of coastal waters for aquaculture, eutrophication and unusual climatological changes (Hallegraeff 1993). Outbreaks of these species are a constant threat to public health worldwide. Have a negative impact on the marine ecosystem, and cause severe economic losses to aquaculture, fisheries and tourism (Lagos, 1998). Outbreaks associated with DSP have been reported in the southern Chilean Patagonian fjords since 1970 (Muñoz et al., 1992; Uribe et al., 2001; García et al., 2003, 2004, 2005). Presently, the X Region of Southern Chile, where the Seno de Reloncaví is located, shows the endemic pres-

Correspondence: Néstor LAGOS (E-mail: nlagos@med.uchile.cl) 
ence of DSP toxins (Lagos, 1998; Uribe et al., 2001; García et al., 2003, 2004, 2005). Moreover, detection of DTX-3 has also been reported in shellfish samples collected in this Region (García et al., 2004).

Diarrheic Shellfish Poisoning (DSP), is the syndrome caused by diarrheic shellfish toxins (DSP toxins), characterized by a toxic symptomatology that develops within $30 \mathrm{~min}$ to $6 \mathrm{hr}$ after contaminated bivalve consumption, including diarrhea $(60 \%)$, nausea $(46 \%)$, vomits $(31 \%)$, and abdominal pain $(77 \%)$. If intoxication level is mild, the syndrome favorably evolves toward total recovery into one to three days illness. No fatalities have been recorded (Yasumoto et al., 1978; Hamano et al., 1986; Aune et al., 1998; García et al., 2003, 2004, 2005).

The DSP toxins are 38 carbons lipophylic polyethers, among which stand out Okadaic Acid (OA), Dinophysistoxin-1 (DTX-1) and Dinophysistoxin-2 (DTX-2), produced by dinoflagellates of the genre Dinophysis sp and Prorocentrum sp (Yasumoto et al., 1979; Lee et al., 1989; Yasumoto and Murata, 1993). The DSP toxins are accumulated by filter bivalves which agglomerate $80 \%$ of toxins in their digestive gland. Depending on the bivalvular refill and natural rate of depuration, the DSP toxins can be metabolically modified inside the bivalves. Due to their chemical stability and lipophylic nature, normal shellfish cooking or steaming does not reduce the toxic effect of DSP toxins (Hu et al., 1992a, 1992b; Gestal-Otero, 2000). In mussel tissues DTX-1 is esterified in the hydroxyl group of Carbon 7. This enzymatic modification is done using fatty acids ranging from tetradecanoic acid (C14:0) to docosahexaenoic acid (C22:6w3), palmitic acid being the most common fatty acid found in DTX1 , of which $90 \%$ is linked to the $7-O$-acyl-derivative of dinophysistoxin-1 named Dinophysistoxin-3 (DTX-3) (Yasumoto et al., 1985).

The Vibrio parahaemolyticus is a gram-negative, halophylic bacterium that inhabits warm estuarine waters worldwide and causes gastroenteritis linked to consumption of contaminated raw or undercooked seafood. In addition to diarrhea, its intoxication symptoms include abdominal cramp (82\%), chills (44\%), myalgias $(36 \%)$, self-reported fever $(34 \%)$, headache $(32 \%)$ and vomiting $(29 \%)$. Diarrhea may contain mucus $(21 \%)$ or blood $(7 \%)$. The mean incubation infection period is $15 \mathrm{hr}$ (ranging from 4 to $90 \mathrm{hr}$ ) and the mean duration of illness is 5 days (ranging from 1 to 13 days) (McLaughlin et al., 2005).

The Vibrio parahaemolyticus has been monitored by the Chilean Health Authority after the Summer
2000 outbreaks that intoxicated 1,500 patients. Since, other outbreak occurred from January to March 2004 in Puerto Montt, regulations have been enforced to obligate compulsory notification of this disease to the National Health Authority (González-Escalona et al., 2005). There are no reports of $V$. parahaemolyticus infection before 2004 in this X Region. Analysis of clinical samples showed the presence of the V. parahaemolyticus O3:K6 pandemic clonal group. However, the analysis of shellfish samples during the epidemics of 2004 and 2005 showed that only $53 \%$ of the total shellfish samples analyzed were shown to be V. parahaemolyticus-positive. Moreover, from 50 positive shellfish samples, only three contained detectable levels of the pandemic clone (Fuenzalida et al., 2006). In the 2005 summer season, 3,693 people were intoxicated by shellfish consumption with clinical diagnostics reported in this X Region (Olea et al., 2005).

Because of the symptom similarities between DSP toxins and enteropatogens intoxication, this type of poisoning is frequently associated clinically with that produced by Vibrio parahaemolyticus and Bacillus cereus, which are usually found in bivalves.

In this paper we report the presence of 7- $O$-acylderivative-dinophysistoxin-1 (DTX-3) as the only DSP toxin compound detected in shellfish consumed by humans intoxicated with diarrhetic symptoms. These patients were clinically associated with the presence of Vibrio parahaemolyticus in Puerto Montt City, Seno de Reloncaví, Southern Chile.

\section{MATERIALS AND METHODS}

\section{Reagents}

Okadaic acid (OA) and Dinophysistoxin-1 (DTX-1), standard toxins, were obtained from SIGMA (Sigma Chemical Co, St, Louis, Mo, USA); 9-antryldiazomethane (ADAM) was purchased from Molecular Probes (USA); deoxycholic acid (DOCA) was purchased from SIGMA (Sigma Chemical Co, St, Louis, Mo, USA); HPLC grade solvents (acetonitrile, diethyl ether, acetone, methanol, dichloromethane, chloroform) were purchased from Merck (MERCK, Darmstadt, Germany); the SEP-PAK ${ }^{\circledR}$ Cartridges for solid phase extraction of Silica and C-18 were purchased from Waters Corporation (Division of MILLIPORE, Milford, Ma. USA); dichloromethane and hexane, used for extraction and clean-up (Mallinckrodt, USA); glass distillation was used when solvent quality did not meet the requirements of purity specified by standard operation procedures (SOP); water of high purity grade 
DINOPHYSISTOXIN-3 in Mytilus chilensis associated to human intoxication.

was obtained by elution through an ion exchange cartridge, and then by boiling for $2 \mathrm{hr}$ with nitrogen bubbling.

\section{Mouse Bioassay of DSP toxins}

The Bioassay was done according to Yasumoto et al. (1980). Twenty- gram samples of homogeneized hepatopancreas are extracted thrice with $100 \mathrm{ml}$ of acetone. The extracts are filtered, then the filtrate is collected and the solvent removed by rotary evaporation. The residue consists of up to $20 \mathrm{ml}$ of water and the suspension extracted thrice with $50 \mathrm{ml}$ of diethyl-ether. The combined organic layers are backwashed twice with small quantities of water and evaporated to dryness. As in the original procedure described above, the residue is resuspended in $1 \%$ Tween 60 solution to a concentration of $5 \mathrm{~g}$ hepatopancreas/ml Tween 60 prior to intraperitoneal injection into each of three mice (CF1) weighing $18 \mathrm{~g}$. Initially, 1 mouse unit (MU) was defined as the minimum dose of toxin required to kill a $16-20 \mathrm{~g}$ mouse within $24 \mathrm{hr}$.

\section{Mussel extraction and analytical High-Perfor- mance liquid chromatography}

The mussel extracts were obtained from shellfish samples collected on February 2005 from the X Region of Chile. Two grams of the digestive glands were removed from Mytilus chilensis (Blue mussel), then homogenized and extracted twice with $3 \mathrm{ml}$ of chilled $80 \%$ methanol, under mechanical stirring using a tissue tearer (BioHomogenizer M 133/2280, Biospec Products, Inc., Bartlesville, OK, USA). Then the methanolic phase was centrifuged at $1,500 \times \mathrm{g}$ for $5 \mathrm{~min}$. and $2.5 \mathrm{ml}$ of the supernatant diluted with water to a final $26.66 \%$ methanol. $5 \mathrm{ml}$ from this dilution were then transferred to a $250 \mathrm{mg} \mathrm{C}-18 \mathrm{SEP}^{\mathrm{PAK}}{ }^{\circledR}$ cartridge. The system was washed with $5 \mathrm{ml}$ of $50 \%$ methanol. Then $5 \mathrm{ml}$ of pure methanol were added, in order to elute the DSP toxins, and this eluted fraction was evaporated to dryness under reduced pressure in a Speed Vac Plus (Savant, SC 210A, Farmingdale, NY. USA). The clean and dry extracts were used for derivatization with ADAM.

The HPLC chemical analysis was performed on a Shimadzu Liquid Chromatograph System equipped with a pump (Shimadzu LC-6A), a Rheodyne injector (7725i Rheodyne. Cotati, Ca. USA) and a Fluorescence detector (Shimadzu RF-535). $10 \mu \mathrm{l}$ of sampled toxins derivatives were injected on a reverse phase column Supelcosil LC-18 (5 $\mu \mathrm{m} ; 25 \mathrm{~cm} \times 4 \mathrm{~mm})$ (Supelco, Bellefonte, PA. USA). An isocratically mobile phase of $\mathrm{CH}_{3} \mathrm{CN} / \mathrm{CH}_{3} \mathrm{OH} / \mathrm{H}_{2} \mathrm{O}$ 8:1:1 (v/v) with a flow rate of $1 \mathrm{ml} / \mathrm{min}$ was run at room temperature. The excitation and emission wavelengths were set at 365 and $415 \mathrm{~nm}$ respectively. Peaks in the resulting chromatograms were identified by comparison with the retention times of each DSP phycotoxin analytical standard.

\section{Alkaline hydrolysis esterifies DSP toxins}

The hydrolysis of the extracts was done according to García et al. (2004). In this case, $2.5 \mathrm{ml}$ of $0.5 \mathrm{~N}$ $\mathrm{NaOH}$ in $90 \%$ methanol solution were added to a 2.5 $\mathrm{ml}$ aliquot of the $80 \%$ methanol extract of each shellfish sample. The mixture was heated for $50 \mathrm{~min}$ at $75^{\circ} \mathrm{C}$. After evaporating the methanol from the reaction mixture, the aqueous layer was acidified with 0.5 $\mathrm{N} \mathrm{HCl}$ and then extracted twice with $5 \mathrm{ml}$ of diethyl ether. After evaporating the solvent, the extracts were dissolved in $2.5 \mathrm{ml}$ of $80 \%$ methanol and extracted twice with $2.5 \mathrm{ml}$ of hexane. Additionally, $1 \mathrm{ml}$ of $0.2 \%$ acetic acid was added to the methanolic solution, with the resulting toxin solution extracted with $4.0 \mathrm{ml}$ of dichloromethane. This eluted fraction was evaporated to dryness under reduced pressure in a SpeedVac Plus (Savant, SC 210A, Farmingdale, NY) and then derivatized.

\section{Derivatization of DSP phycotoxins with ADAM}

The derivatization of standards and extracts of toxin samples were carried out according to García et al. (2003). Briefly, the solid mussel extract residues or standards were treated with a freshly prepared solution of $0.1 \%$ ADAM (in $100 \mu \mathrm{l}$ of acetone and $400 \mu \mathrm{l}$ of methanol) (Lee et al., 1987). After $1 \mathrm{hr}$ at $25^{\circ} \mathrm{C}$ in the dark, samples were evaporated to dryness and the residues diluted in $200 \mu \mathrm{l} \mathrm{CH}_{2} \mathrm{Cl}_{2} /$ hexane, $1: 1(\mathrm{v} / \mathrm{v})$ and then transferred into a $500 \mathrm{mg}$ Silica gel SEP PAK ${ }^{\circledR}$ cartridge. Each system was washed successively with 5 $\mathrm{ml}$ of $\mathrm{CH}_{2} \mathrm{Cl}_{2} /$ hexane, 1:1 (v/v) and $5 \mathrm{ml} \mathrm{CH}_{2} \mathrm{Cl}_{2}$ and finally eluted with $5 \mathrm{ml}$ of $\mathrm{CH}_{2} \mathrm{Cl}_{2} /$ methanol, $1: 1(\mathrm{v} / \mathrm{v})$. The last fractions were evaporated to dryness, each one dissolved in $1 \mathrm{ml}$ methanol, and then $10 \mu \mathrm{l}$ samples injected and analyzed by HPLC with fluorescence on line detection (HPLC-FLD).

\section{Analysis of Vibrio parahaemolyticus}

Feces samples collected from patients were forwarded to the Instituto de Salud Pública laboratory and tested for Vibrio parahaemolyticus. Enrichment, isolation, enumeration, screening and confirmation were performed as described in the Bacteriological Analyti- 
cal Manual of the US Food and Drug Administration (Kaiser and DePaola, 2004).

\section{Collection and analysis of phytoplankton}

Phytoplankton samples were collected using a Rutner net with a $10.4 \mathrm{~cm}$ mouth opening and mesh size of $20 \mu \mathrm{m}$. Vertical hauls were carried out from 15 meters depth. The phytoplankton sample (water sample) were examined directly in the living state and in samples preserved with Lugol's iodine solution.

Toxic species were first identified using a Zeiss inverted microscope and then counted according to the standard Utermöhl technique (Utermöhl 1958). The result of the counting was expressed by liter, thus establishing the numerical density of toxic species and total phytoplankton. The taxonomic analyses were also performed by direct observation with a contrast phase microscope Unilux-12.

\section{Analyses of lipid content}

The shellfish tissues were homogenized with 2.0 $\mathrm{g}$ of sodium sulfate anhydrous and then extracted with $180 \mathrm{ml}$ dichloromethane for $8 \mathrm{hr}$ under reflux with Soxhlet extraction apparatus. This extract was reduced to a $1 \mathrm{ml}$ volume for Kuderna-Danish concentrators at $60^{\circ} \mathrm{C}$. Then $20 \mu \mathrm{l}$ of the sample were weighed using an analytical balance. The data of the lipid content analysis correspond to eight samples collected in each monitoring site (black dots in the map, Fig. 1) and are expressed in Fig. 4 and Table 1, as Average \pm Standard Deviation, $\mathrm{n}=8$.

\section{RESULTS}

A total number of 35 patients were intoxicated, ten children $(8.9 \pm 1.6$ years; mean $\pm \mathrm{SEM}, \mathrm{N}=10)$ and twenty five adults $(39.3 \pm 3.5$ years; mean \pm SEM, $\mathrm{N}=25$ ). They arrived at the local Emergency Room of Puerto Montt Hospital in January 2005, exhibiting symptoms of digestive intoxication. They reportedly had eaten Chilean blue mussels (Mytilus chilensis) two hours before, in a place near Angelmo in the Seno de Reloncaví ( $41^{\circ} 28^{\prime}$ L.S.-72 $2^{\circ} 56^{\prime}$ L.W.). Patient's symptoms were as follows: nausea (35\%), vomiting (26\%), abdominal pain $(85 \%)$ and diarrhea $(75 \%)$. The most frequent complaints were associated with intense abdominal pain and fluid diarrhea.

After the intoxication crisis, a monitoring program for Vibrio parahaemolyticus was activated in this area. Search for Vibrio parahaemolyticus was negative for all mussel samples tested during this period (Insti- tuto de Salud Pública de Chile). Samples also tested negative for the DSP toxins mouse bioassay (Servicio Salud Puerto Montt). The mouse bioassay is one of the customary methods to detect DSP toxins in shellfish extract (Yasumoto et al., 1978).

The plankton sample, collected by horizontal dragging in the Seno de Reloncaví area, showed the presence of Dinophysis acuta, a worldwide dinoflagellate DSP toxin producer, also present in Chilean coastal waters (Hernández, 2005. Personal Communication). Fig. 1 shows a map of Seno de Reloncaví in which the DSP-contaminated Blue mussel samples were collected (Zone 1: $41^{\circ} 41.5^{\prime} \mathrm{S}-72^{\circ} 37^{\prime} \mathrm{W}$; Zone 2: $41^{\circ} 25^{\prime} \mathrm{S}-72^{\circ} 18^{\prime} \mathrm{W}$; Zone 3 : $42^{\circ} 17 ' \mathrm{~S}-72^{\circ} 49^{\prime} \mathrm{W}$; Zone 4 : $41^{\circ} 36.5^{\prime} \mathrm{S}-72^{\circ} 25^{\prime} \mathrm{W}$; Zone 5: $41^{\circ} 30.00^{\prime} \mathrm{S}-72^{\circ} 55^{\prime} \mathrm{W}$; Zone 6: $41^{\circ} 31 \mathrm{~S}-72^{\circ} 52 \mathrm{~W}$; Zone $7: 42^{\circ} 26^{\prime} \mathrm{S}-72^{\circ} 15^{\prime} \mathrm{W}$; Zone $3: 41^{\circ} 17^{\prime} \mathrm{S}-73^{\circ} 46^{\prime} \mathrm{W}$ ). The mussel sample extracts testing negative for the DSP toxin mouse bioassay were analyzed by HPLC-FLD according to the derivatization conditions described by García et al. (2003). Fig. 2A shows the chromatographic run of mussel extract esterified with ADAM, a fluorescent chromophorus, and as detected by HPLC-FLD. Fig. 2A shows the typical mussel sample extract chromatogram, here with only a small amount of DTX-1 toxin detected (range, $1.9 \pm 1.5$ to $11.7 \pm 4.6 \mathrm{ng} / \mathrm{g}$ hepatopancreas; mean \pm SEM, $N=6$ ). The DTX-1 toxin yielded a single peak showing a retention time of 11:15 min. When the mussel extracts were treated by an alkaline hydrolysis procedure, the amount of DTX-1 increased to $274.7 \pm 7.4 \mathrm{ng} / \mathrm{g}$ hepatopancreas (mean $\pm \mathrm{SEM}$, $\mathrm{N}=6$ ), showing the chemical transformation between 7-O-acyl-derivatives of dinophysistoxin-1 (DTX-3) into DTX-1 (Fig. 2B). Contents of DTX-1 and DTX-3 in the extracts of mussel samples collected in eight places of the Seno de Reloncaví are shown in (Table I). The levels of total DTX-1 equivalent, ranged from $160.2 \pm 13.2$ to $320.4 \pm 5.6 \mathrm{ng} / \mathrm{g}$ hepatopancreas (mean \pm SEM, N=6). When DTX-1 standard is spiked into dichloromethane-clean extracts the average recoveries were $97 \%$ when compared with standard solutions. Fig. 2C shows the DTX-1 analytical standard chromatogram of the spiked sample.

Fig. 3 shows the DTX-3 percentage as a function of the total content of DTX-1- equivalent (ng/g hepatopancreas) in the blue mussel extracts analyzed. The percentage of Dinophysistoxin-3 ranged from 96 to $99 \%$, meaning that DTX-1 was in its esterified form in percentage above $96 \%$ in the blue mussel samples analyzed.

Fig. 4 shows the amount of DTX-3 (ng/g hepato- 
DINOPHYSISTOXIN-3 in Mytilus chilensis associated to human intoxication.

pancreas) as a function of the total lipid content of the blue mussel digestive gland dry mass extracts. All samples showed a direct relation between the high levels of total lipid contents and the level of DTX-3. The DTX3 toxin contents are higher in zones with high lipid contents of 23.6 to $24.7 \%$ (mean \pm SEM, $N=6$ ), showing a clear affinity of the toxin for a lipidic environment.

\section{DISCUSSION}

Data collected in this paper suggest that the massive human intoxications produced by consumption of bivalves are mainly associated to DTX-1 which originates from its esterified form of 7-O-acyl-derivatives of dinophysistoxin-1 (DTX-3) instead of epidemiologic association with Vibrio parahaemolyticus as the preliminary diagnostics done by the Physicians in the Emergency Room.

The $O$-acyl-derivative dinophysistoxin-1 was not detected by the customary mouse bioassay method, and consequently the shellfish was authorized for sale at the local market. The fact that all of the victims consumed blue mussels after heat cooking reduced the possibility of bacterial contamination but not of intoxication with DSP-toxins, which are heat- stable.

Since the $O$-acyl-derivative dinophysistoxin-1 (DTX-3) was the major toxic component found in shellfish sample extracts, a possible explanation for the diarrheic symptoms and the intoxication syndrome showed by the patients would be the metabolic transformation of $O$-acyl-derivative dinophysistoxin-1 (DTX-3) into Dinophysistoxin-1 (DTX-1) inside the patients digestive tract (García et al., 2005).

The negative results for enteropathogens analysis in patient fecal samples and the negative mouse bioassay for DSP toxins strengthens this hypothesis. The metabolic transformation of DTX-3 into DTX-1 should occur in the digestive tract, mainly in the stomachs of poisoned patients. Enzymes such as lipases and

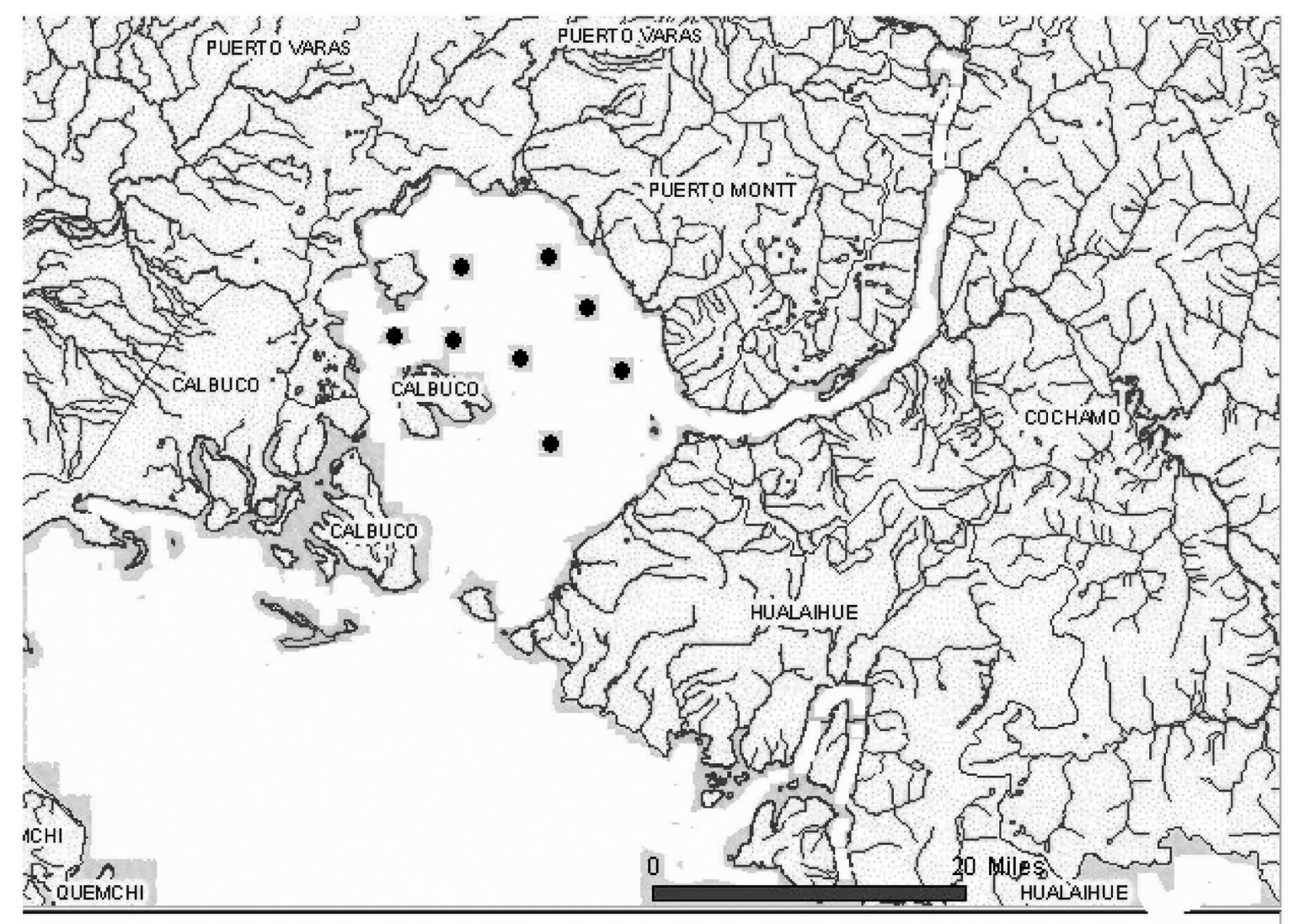

Fig. 1. Map of Seno de Reloncaví in Puerto Montt city, X Region, Chile. The dot () show the littoral places where the DSP-contaminated shellfish were collected by the monitoring program after the intoxication. 


\section{GARCÍA et al.}

esterases, which normally digest daily nutrients and xenobiotics, can hydrolyze DTX-3 by converting it into DTX-1, the most potent DSP toxin (Rivas et al., 2000). DTX-1 was responsible for the intoxication
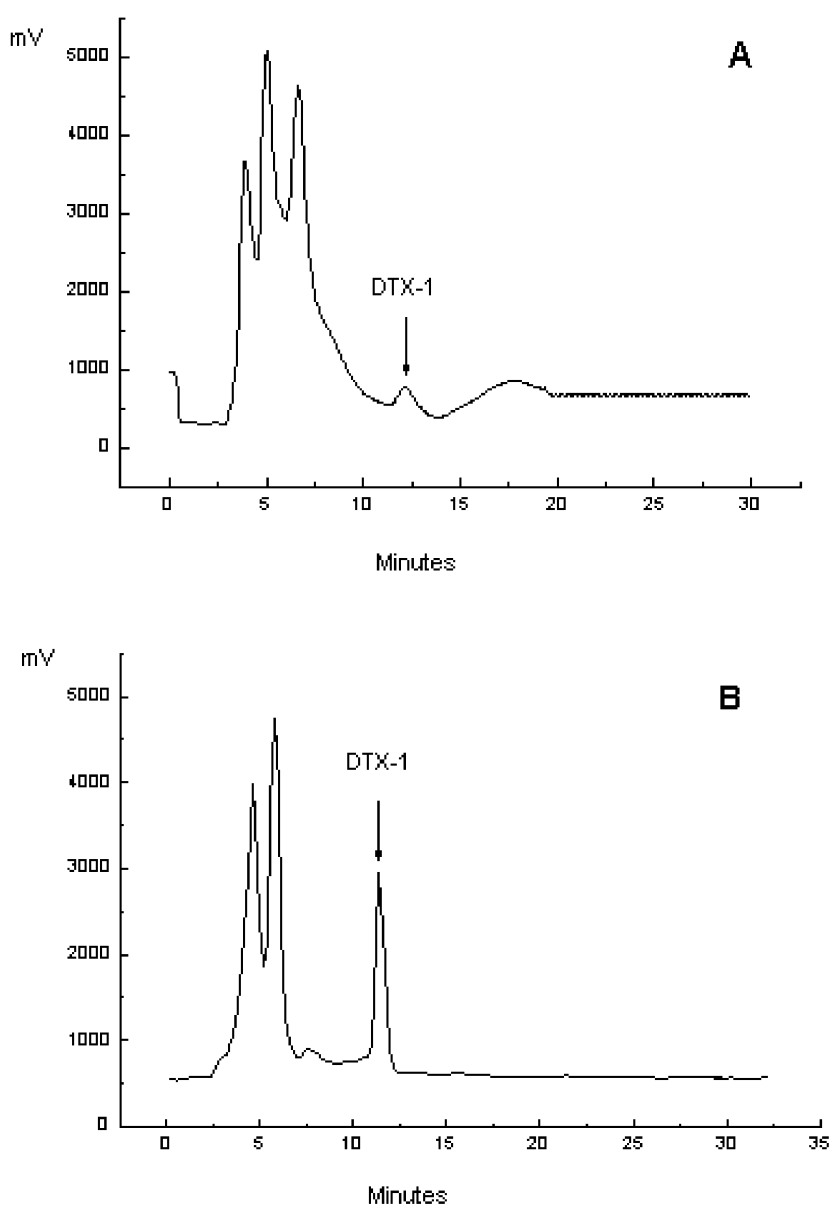

syndrome suffered by the patients. The fast appearance of the diarrhetic intoxication symptoms, less than $2 \mathrm{hr}$ after shellfish consumption reported by the intoxicated patients, also strengthens the hypothesis of DSP intox-

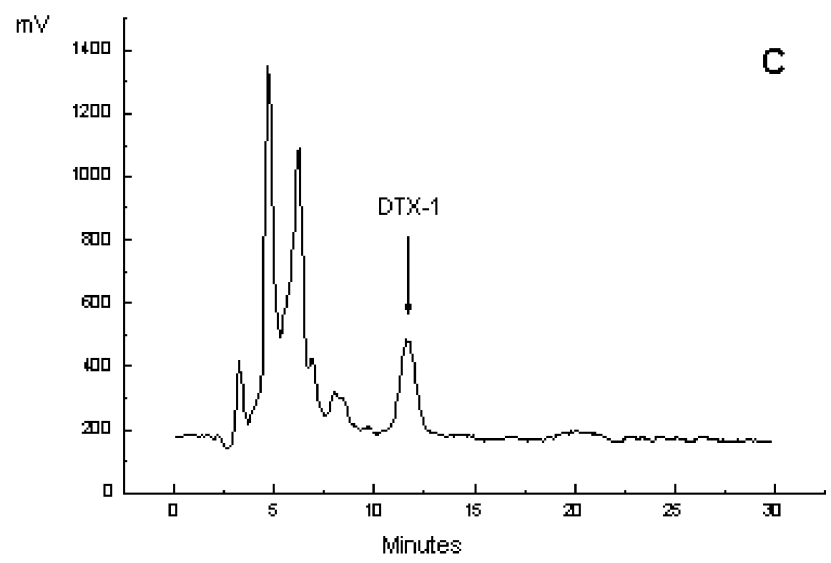

Fig. 2. Chromatograms of DSP toxin standards and blue mussel extract samples. A.- Blue mussel extract without alkaline hydrolysis. B.- Blue mussel extract after $0.5 \mathrm{~N} \mathrm{NaOH}$ treatment (alkaline hydrolysis) . C.- Dinophysistoxin-1 analytical standard (DTX-1).

Table 1. Content of Dinophysistoxin-1 and 7-O-acyl-derivatives of Dinophysistoxins- 1 esters in 8 zones in Seno Reloncavi, X Región. The data is expressed as Average \pm Standard Deviation, $n=8$.

\begin{tabular}{c|c|c|c|c}
\hline Origin of Sample Blue mussels & Free DTX -1 (ng/g) & DTX -3 (ng/g) & Total DTX-1 equivalent (ng/g) & OA esters \% \\
\hline Zone 1 & $6,1 \pm 1,8$ & $220,5 \pm 5,0$ & $226,6 \pm 3,9$ & 98 \\
Zone 2 & $2,8 \pm 1,7$ & $275,9 \pm 7,0$ & $278,7 \pm 6,1$ & 98 \\
Zone 3 & $9,4 \pm 2,4$ & $311,1 \pm 4,8$ & $320,4 \pm 5,6$ & 97 \\
Zone 4 & $1,9 \pm 1,5$ & $158,2 \pm 13,1$ & $160,2 \pm 13,2$ & 96 \\
Zone 5 & $11,7 \pm 4,6$ & $270,5 \pm 7,0$ & $282,2 \pm 10,5$ & 96 \\
Zone 6 & $11,1 \pm 2,1$ & $199,4 \pm 3,7$ & $210,5 \pm 4,2$ & 99 \\
Zone 7 & $2,8 \pm 1,7$ & $190,3 \pm 6,8$ & $193,1 \pm 6,8$ & 97 \\
Zone 8 & $4,7 \pm 3,0$ & $274,7 \pm 7,4$ & $279,4 \pm 7,2$ & 99 \\
\hline
\end{tabular}


DINOPHYSISTOXIN-3 in Mytilus chilensis associated to human intoxication.

ication, since enteropathogens need incubation periods of at least of $12 \mathrm{hr}$ to produce diarrhetic symptoms (McLaughlin et al., 2005).

The presence of DTX-3 in Chilean shellfish is not unusual in samples collected in this area. Moreover, all samples measured by our laboratory in the last five years have shown DTX-1 after alkaline hydrolysis treatment of the shellfish extract, with this DTX-1 coming from the 7-O-acyl-derivatives of dinophysistoxin-1, making DTX-1 the major DSP toxin in Chilean shellfish samples (Uribe et al., 2001; Lagos, 2002; García et al., 2004). The first report of DSP toxins in Chilean shellfish samples described DTX-1 as the major DSP toxin in Chilean mussel samples (Zhao et al., 1993).

Contaminated mollusks can modify DSP toxins through enzymatic processes, allowing their esterification with fatty acids. This metabolic transformation generates products such as the 7-O-acyl-derivatives of dinophysistoxins (Suzuki et al., 1999; Vale and Sampayo et al., 2002). DSP esterifies toxins do not inhibit Protein Phosphatase activity and therefore show low toxicity in mamms. The covalent binding generates a steric impediment to the carboxyl group, which is a determinant for the inhibition of Protein Phosphatase (Takai et al., 1992). The DTX-1 to 7-O-acylDTX-1 biotransformation is likely to be a route for DTX-1 detoxification in mussels, since DTX-3 does not inhibit protein phosphatases and for that reason exhibits very low toxicity (García et al., 2005). The levels of total DTX-1 equivalent, rangeing from 160.2 \pm 13.2 to $320.4 \pm 5.6 \mathrm{ng} / \mathrm{g}$ hepatopancreas (mean \pm SEM, $\mathrm{N}=6$ ), are over the international safety limit of $200 \mathrm{ng} / \mathrm{g}$ of DSP toxins / gram of hepatopancreas. Moreover, the contaminated shellfish showed DTX-3 amounts of nearly $200 \mathrm{ng} / \mathrm{g}$ hepatopancreas (between $158.2 \pm 13.1$ to $311.1 \pm 4.8 \mathrm{ng} / \mathrm{g}$ hepatopancreas; mean $\pm \mathrm{SEM}, \mathrm{N}=6$ ).

The seasonal variations in the filter bivalve fatty acid composition of the triacylglycerol are well documented (Napolitano and Ackman 1993). The saturated fatty acid composition increases significantly in summer, where the total lipid content of the digestive gland is above $24 \%$ of the dry mass during the period of

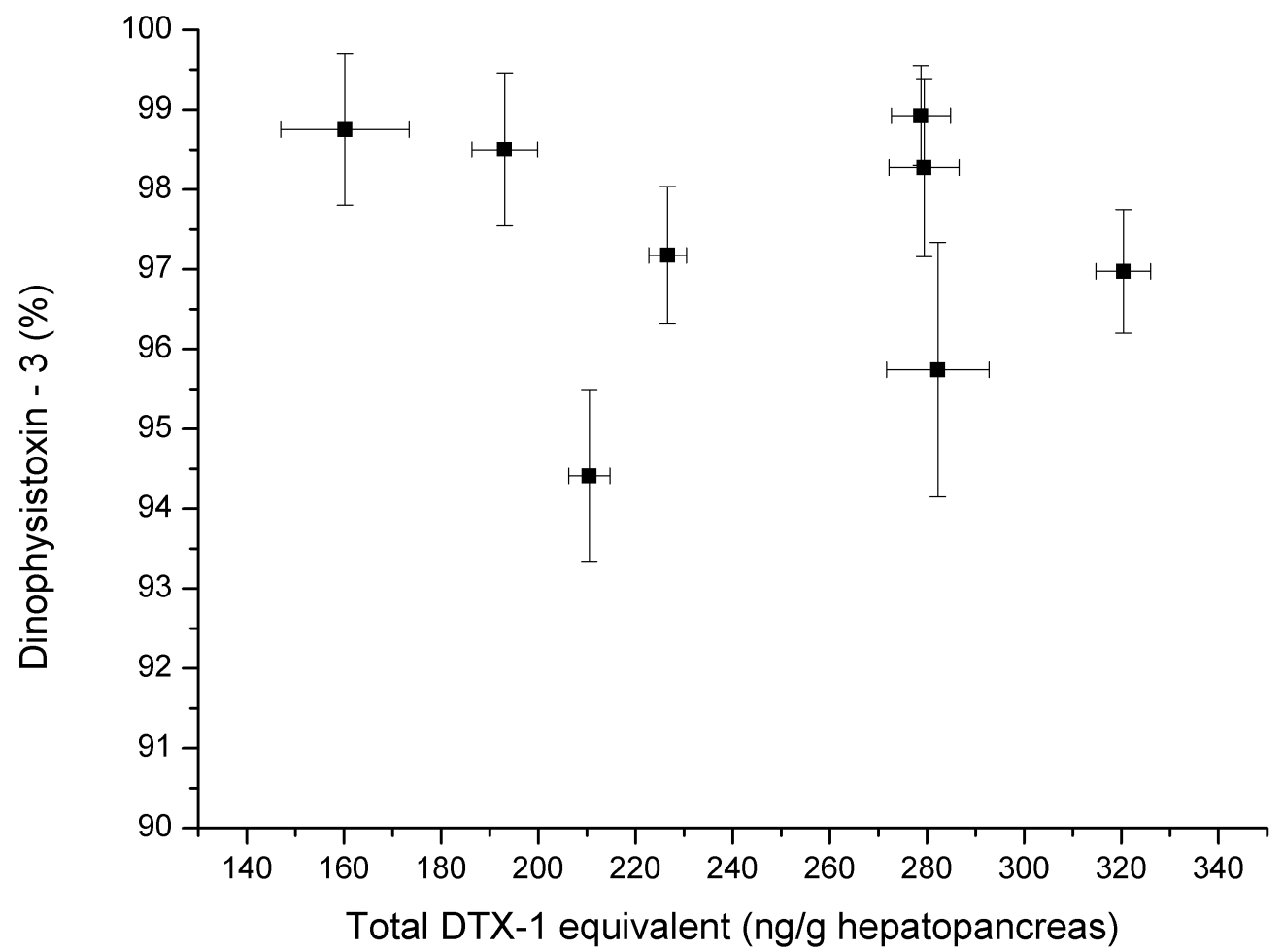

Fig. 3. Content of 7-O-acyl-derivative-dinophysistoxin-1 (DTX-3). Percentages are show as a function of the total content of DTX-1 equivalent (ng/g hepatopancreas). 


\section{GARCÍA et al.}

energy storage, such as the spring - summer period (Pazos et al., 2003). The lipophilic character of the DTX-3 molecule together with the relatively high lipid content of the digestive gland (De Zwaan and Marhiers, 1992) indicates that DTX-3 may have an affinity for lipid-rich cellular and intracellular components such as membranes and lipid droplets (Svensson and Forlan, 2004). The degree of bioaccumulation depends mainly on the hydrophobicity of the contaminant together with the lipid content of the organism. (Svensson, 2002).

In conclusion, since: a) the victims consumed blue mussels after heat cooking, reducing the possibility of bacterial contamination, b) the negative result for the presence of enteropathogens in patient fecal samples, c) the diarrhetic symptoms developed in no more than $2 \mathrm{hr}$ after the shellfish was eaten, and d) the $O$ acyl-derivative dinophysistoxin-1 (DTX-3) was the major toxic component found in shellfish sample extracts, this study suggests that the intoxication symptoms showed by the 35 patients described above are more likely to be associated with to the presence of DSP toxins than with the enteropathogen V. parahaemolyticus in the blue mussel filter bivalve (M. chilensis). This finding also suggests that during the summer period in the Seno de Reloncaví, Puerto Montt, the monitoring of DSP toxin content in shellfish samples should be enforced. Furthermore, the shellfish extracts should be treated by alkaline hydrolysis in order to detect DTX-3 as 7- $O$-acyl-DTX-1, since the DTX-3 to DTX-1 biotransformation in humans has been reported and shown to be responsible for massive intoxication by 7-O-acyl-DTX-1 in contaminated shellfish consumption (García et al., 2005).

\section{ACKNOWLEDGMENT}

L/ICA/ICB/83336/04 OPCW Grant and Fundación Estudios Biomédicos Avanzados (FEBA) Faculty of Medicine, University of Chile. We also want to thank the Instituto de Salud Pública (Santiago, Chile) for information and testing Vibrio parahaemolyticus.

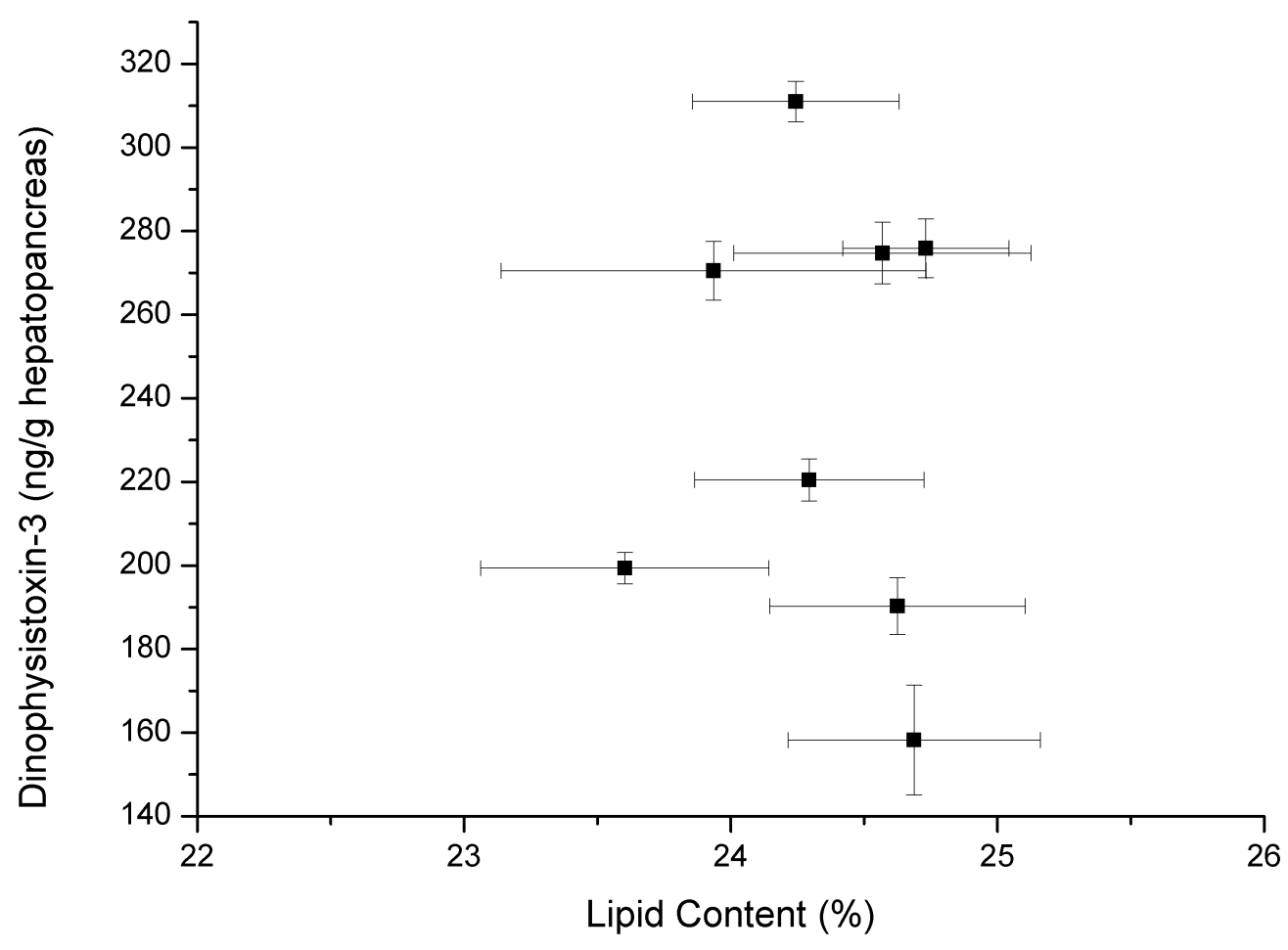

Fig. 4. Lipid content $(\%)$ in mussel tissue and amount of DTX-1 equivalents in hepatopancreas of blue mussel samples collected in Seno de Reloncaví. The data is expressed as Average \pm Standard Deviation, $\mathrm{n}=8$. 
DINOPHYSISTOXIN-3 in Mytilus chilensis associated to human intoxication.

\section{REFERENCES}

Aune, T., Stabell, B., Nordstoga, K. and Tjotta, K. (1998): Oral toxicity in mice of algal toxins from the diarrheic shellfish toxins (DST) complex and associated toxins. J.Nat. Toxins, 7, 141-158.

De Zwaan, A. and Mathie, M. (1992): Cellular energy metabolism in the Mytilidae: An overview. In (Gosling, E., ed.), The Mussel Mytilus: Ecology, Physiology, Genetics and Culture. pp. 223307 Elsevier Amsterdam.

Fuenzalida, L., Hernández, C., Toro, J., Rioseco, M.L., Romero, J. and Espejo, R. (2006): Vibrio parahaemolyticus in shellfish and clinical simples during two large epidemics of diarrhoea in southern Chile. Environ Microbiol., 1-9.

García, C., Pereira, P., Valle, L. and Lagos, N. (2003): Quantitative of diarrhetic shellfish poisoning toxins in chilean mussel using pyrenyldiazomethane, as fluorescent labeling reagent. Biol. Res., 36, $\mathrm{N}^{\circ} 2$. 1-13.

García, C., Gonzalez, V., Cornejo, C., Palma-Fleming, H. and Lagos, N. (2004): First evidence of dinophisistoxin-1 and carcinogenic polycyclic aromatic hydrocarbons in smoked bivalves collected in the patagonic fjords . Toxicon 43, 121-131.

García, C., Truan, D., Lagos, M., Santelices, J.P., Díaz, J.C. and Lagos, N. (2005): Metabolic transformation of dinophysistoxin-3 into dinophysistoxin-1 causes human intoxication by consumption of $o$-acyl-derivatives dinophysistoxins contaminated shellfish. J. Tox. Sci., 30, 287-296.

Gestal-Otero, J.J. (2000): Nonneurotoxic Toxic. In Seafood and Freshwater toxins. Ed: Botana. 4564.

González-Escalona, N., Cachicas, V., Acevedo, C., Rioseco, M.L., Vergara, J.A. and Cabello, F. (2005): Vibrio parahaemolyticus diarrhea, Chile,1998 and 2004. Emerg Infect Dis, 11, 129 -131 .

Hallegraeff, G.M. (1993): A review of harmful algal blooms and their apparent global increases. Phycologia, 32, 79-99.

Hamano, Y., Kinoshita, Y. and Yasumoto, T. (1986): Enteropathogenicity of diarrhetic shellfish toxins in intestinal models. J. Food Hyg. Soc. Jpn., 27, 375-379.

Hernández, C. (2005): Personal Communication.
Informe de Salud Regional X Región Puerto Montt, Febrero 2005.

Hu, T., Marr, J., Defreitas, A.S.W., Quilliam, M.A., Walter, J.A., Wright, J.L.C. and Pleasance, S. (1992a): New diol esters of okadaic acid isolated from cultures of the dinoflagellates Prorocentrum lima and $P$. concavum. J. Nat. Prod., 55, 1631-1637.

Hu, T., Doyle, J., Jackson, D., Marr, J., Nixon, E., Pleasence, S., Quilliam, M.A., Water, J.A. and Wright, J.L.C. (1992b): Isolation of a new diarrhetic shellfish poison from Irish mussels. J.Chem. Soc. Chem. Commum., 30, 39-41.

Kaiser, C.A. and Depaola, A. (2004): Bacteriological Analytical Manual on line. Vibrio US Food and Drug Administration. Center for Food Safety and Applied Nutrition. USFDA, 1-26.

Lagos, N. (1998): Microalgal blooms: A global issue with negative impact in Chile. Biol. Res., 31, 375-386.

Lagos, N. (2002): Principales toxinas de origen fitoplanctónico: Identificación y cuantificación mediante cromatografía líquida de alta resolución (HPLC). Floraciones Algales Nocivas en el Cono-Sur Americano. Sar,E.A, M.E.,Ferrario \& B., Reguera. Instituto Español de Oceanografía, 2002.

Lee, J.S., Yanagi, T., Kenma, R. and Yasumoto, T. (1987): Fluorometric determination of diarrhetic shellfish toxins by high-performance liquid chromatography. Agric. Biol. Chem., 51, 877881.

Lee, J.S., Igarashi, S., Fraga, E., Dahl, P., Hovgaard, T. and Yasumoto, T. (1989): Determination of diarrhetic shellfish toxins in various dinoflagellates species. J. Appl. Phycol., 1, 147-152.

McLaughlin, J.B., DePaola, A., Bopp, C.A., Martinek, K.A., Napolilli, N.P., Allison, C.G., Murray, S.L., Thompson, E.C., Bird, M.M. and Middaugh, J.P. (2005): Outbreak of Vibrio parahaemolyticus gastroenteritis associated with Alaskan oysters. N. Engl. J. Med., 353, 14631470.

Muñoz, P., Avaria, S., Sievers, H. and Prado, R. (1992): Presencia de dinoflagelados tóxicos del genero Dinophysis en el seno de Aysén. Chile. Rev. Biol. Mar, Valparaiso, 27, 187-212.

Napolitano, G.E. and Ackman, R.G. (1993): Fatty acids dynamics in sea scallops Placopecten magellanicus (Gmelin, 1791) from Georges Bank, Nova Scotia. J. Shellfish Res., 121, 267- 
277.

Olea, A.M., González, C., Chiu, M., Vallebuona, C., Labraña, M. and Martiniello, F. (2005): Brote de gastroenteritis por Vibrio parahaemolyticus en Chile. Revista Chilena de Salud Pública, 9, 5153.

Pazos, A., Sánchez, J., Román, G., Pérez-Parallé, L. and Abad, M. (2003): Seasonal changes in lipid classes and fatty acid composition in the digestive gland of Pecten maximus. Comp Biochem. Phys B., 134, 367-380.

Rivas, M., García, C., Liberona, J.L. and Lagos, N. (2000): Biochemical characterization and inhibitory effects of dinophysistoxin-1, okadaic acid and microcystine L-R on protein phosphatase 2A purified from the mussel Mytilus chilensis. Biol. Res., 33, 197-206.

Svensson, S. (2002): Depuration of okadaic acid (Diarrhetic Shellfish Toxin) in mussels Mytilus edulis (Linnaeus), feeding on different quantities of nontoxic algae. Aquaculture, 62172, 115.

Svensson, S. and Forlan, L. (2004): Analysis of the importance of lipid breakdown for elimination of okadaic acid (diarrhetic shellfish toxin) in mussels, Mytilus edulis: results from a field study and a laboratory experiment. Aquat Toxicol., 66, 405-418.

Suzuki, T., Ota, H. and Yamasaki, M. (1999): Direct evidence of transformation of dinophysistoxin-1 (dinophysistoxin-3) in the scallop Patinopecten yessoensis. Toxicon, 37, 187-198.

Takai, A., Murata, M., Torigoe, K., Isobe, M. and Mieskes, G. (1992): Inhibitory effects of okadaic acid derivatives on protein phosphatases: A study on structure-affinity relationship. Biochem. J., 284, 539-544.

Uribe, J.C., García, C., Rivas, M. and Lagos, N. (2001): First Report of Diarrhetic Shellfish Toxins in Magellanic Fiords, Southern Chile. J.
Shellfish Res., 20, 69-74.

Utermöhl, H. (1958): Zur Vervollkommung der quantitativen phytoplankton-methodik Mitt Int. Ver Limnol, 9, 1-38.

Vale, P. and Sampayo, M.A. (2002): First confirmation of human diarrhoeic poisonings by okadaic acid esters after ingestion of razor clams (Solen marginatus) and green crabs (Carcinus maenus) in Aveiro lagoon, Portugal and detection of okadaic acid esters in phytoplankton. Toxicon, $\mathbf{4 0 ,}$ 989-996.

Yasumoto, T., Oshima, Y. and Yamaguchi, M. (1978): Ocurrence of a new type of shellfish poisoning in the tohoku distric. Bull. Jpn. Soc. Sci. Fish., 44, 1249-1255.

Yasumoto, T., Oshima, Y. and Yamaguchi, M. (1979): Ocurrence of a new type of shellfish poisoning in Japan and chemical properties of the toxin. In Taylor, D. and Seliger, H.H., eds.), Toxic Dinoflagellate Blooms, pp. 495-502. Elsevier, Amsterdam.

Yasumoto, T., Oshima, Y., Sugawara, W., Fukuyo, Y., Oguri, H., Igarashi, T. and Fujita, N. (1980): Identification of Dinophysis fortii as the causative organism of diarrhetic shellfish poisoning. Bull. Jpn. Soc. Sci. Fish., 46, 1405-1411.

Yasumoto, T., Murata, M., Oshima, Y., Sano, M., Matsumoto, G.K. and Clardy, J. (1985): Diarrhetic shellfish poisons. Tetrahedron., 41, 10191025.

Yasumoto, T. and Murata, M. (1993): Marine Toxins. Chem Rev, 93, 1879-1909.

Zhao, J., Lembeye, G., Cenci, G., Wall, B. and Yasumoto, T. (1993): Determination of okadaic acid and dinophysistoxin-1 in mussels from Chile, Italy and Ireland. In Toxic Phytoplankton Bloooms in the Sea. (Smayda, T.J. and Shimizu, Y., eds.), Elsevier Science Publishers, pp. 587592 Amsterdam, The Netherlands. 